\title{
XXI FÓRUM DE PESQUISA EM CIRURGIA
}

\section{RESEARCH SUMMIT IN SURGERY}

\section{Ruy Garcia Marques, TCBC \\ Coordenador do XXI Fórum de Pesquisa em Cirurgia}

Tradicionalmente, a Cirurgia é definida como a parte Colégio Brasileiro de Cirurgiões realizou o XXI Fórum de Pesquisa em Cirurgia, evento que vem sendo realizado anualmente, desde 1986. O Fórum se caracteriza por incentivar a divulgação do trabalho de Núcleos de Pesquisa Cirúrgica Experimental de todo o País, reunindo cirurgiões e alunos (de Graduação e de Pós-Graduação), de diferentes formações dentro da área da Saúde. Trata-se, pois, de oportunidade para se cotejar resultados e métodos de trabalhos, bem como para a troca de idéias e experiências, indispensáveis para a evolução da Cirurgia.

Neste ano, foi apresentado um número expressivo de trabalhos de grande relevância, com a participação de pesquisadores oriundos de diversos Estados, mostrando a importância que a Comunidade Científica Brasileira vem dispensando à sua realização. Com a publicação dos resumos dos trabalhos na Revista do Colégio Brasileiro de Cirurgiões, agora indexada na base de dados Scielo, a visibilidade do evento assume porte ainda maior e, sem dúvida, possibilita a sua ampla divulgação. Certamente, esse fato se constituirá em grande estímulo para o incremento da produção científica nacional e para um maior número de participantes nas versões futuras do Fórum. êutica médica que se dedica ao tratamento de doenças da terapêutica médica que se dedica ao tratamento de doenças
e traumatismos por meio de processos operatórios manuais e instrumentais. Ainda que permaneça e seja plenamente válida essa definição, o cirurgião, afora o grande desenvolvimento de aspectos técnicos de importância inquestionável, se voltou para as ciências básicas, buscando respostas que visam ao restabelecimento e à manutenção da função orgânica, no pré-, per- e pós-operatório. Assim, estudos relacionados à resposta inflamatória à lesão, função imune, metabolismo, química, física e genética, dentre muitos outros, realizados em conjunto com um grande contingente de profissionais das áreas básica e clínica, há muito passaram a fazer parte de seu cotidiano.

Os últimos 150 anos assistiram o grande progresso da Cirurgia. Nas últimas décadas desponta um grande interesse na pesquisa e passa a existir mútua colaboração entre a Cirurgia e a Ciência Médica Básica, em uníssono com a importante contribuição tecnológica. A Cirurgia atual representa uma mera transição entre o passado e o futuro e muito do que antes era inconcebível e inimaginável tornou-se realidade. Considerando-se todo o grande avanço ocorrido, é impossível se especular sobre o futuro da Cirurgia. No início, predominava a arte, mas o enfoque atual vem, sobretudo, da Ciência: Cirurgia - Arte e Ciência. 